\title{
Who's Afraid of 1619?: Pedagogy, Race, and Class in the United States
}

\author{
Cody R. Melcher ${ }^{1}$ (D)
}

Accepted: 8 January 2021 / Published online: 8 March 2021

(C) The Author(s), under exclusive licence to Springer Nature B.V. part of Springer Nature 2021

I grew up in a working class neighborhood in Metropolitan Detroit, about ten minutes, by car, from Detroit's major airport where my father worked as a mechanic. I attended Belleville High School, known - if it is known for anything — as the alma mater of the Belleville Three, the founding fathers of techno music. Belleville High School was and is, like most public schools that serve the working class, profoundly underfunded, overcrowded, and staffed by overworked, underpaid, and, in some cases, underqualified teachers. Belleville High School is unique among working class public schools, however, in that its student body is almost exactly half Black and half white. ${ }^{1}$ As a "School of Choice," students who live outside of the district's catchment area are able to attend (often given the caveat that students from outside the catchment area are responsible for their own transportation to and from school). This gives the high school an eclectic mix of rural whites, suburban whites and Blacks from the relatively integrated mobile home parks and subdivisions nearby, and urban Blacks escaping the true atrocity that is the Detroit Public School system.

As a junior, I registered for a class on the history of the US Civil War. I wasn't particularly interested in the Civil War, or war in general, but electives were rare, and the class was taught by a popular teacher who many of my classmates adored. Above all, he was charismatic, idiosyncratic, and intimidating. A tall white man, with an imposing gait, and a military-style crewcut, very few dared to misbehave in his class (or even in the hallway near his classroom). I was immediately intrigued: the class, he announced on the first day, would have a thesis. None of the classes I'd taken before (and few since) had the primary intention of proving a point. What was that point? The US Civil War was not caused by slavery.

My memory regarding the specifics of his argument is now foggy, but I do recall his extreme reverence for Robert E. Lee and other Confederate leaders, brave men who fought for their interpretation of the Constitution, not slavery. He called his favorite students not by name, but by the name of a Confederate leader who they reminded him of. I was nicknamed

\footnotetext{
${ }^{1}$ According to the latest data, of the 1674 students currently enrolled at the school, $48 \%$ are Black (non-Hispanic), while $44 \%$ are white (non-Hispanic) (US News 2020). While enrollment has decreased since I graduated in 2009-from over 2000 students — the racial demographics have remained fairly constant.
}

Cody R. Melcher

crmelch@umich.edu

1 Department of Sociology, The Graduate Center, City University of New York, New York, NY, USA 
"Stonewall Jackson," after the well-known Confederate general, whose military genius and untimely — for the Confederacy — end apparently reminded him of me.

If you asked me when I graduated high school in 2009 what my favorite class had been, I likely would have answered: History of the US Civil War. It was one of the very few classes I took where the teacher seemed legitimately interested in what they were teaching, and that enthusiasm wore off on many of his students. Of course, I now know that essentially everything he said was Lost Cause nonsense, delusions of someone I now regard as a malignant white supremacist. But, as a high schooler - wide-eyed, eager to learn - a child with no reason to question the authority of a widely admired educator, I believed him. And so did (and do) countless students at Belleville High School.

The New York Times' 1619 Project is a comprehensive attempt to "reframe [the United States'] history by placing the consequences of slavery and the contributions of black Americans at the very center of [the] national narrative." Developed in part by journalist Nikole Hannah-Jones, the Project currently consists of a full issue of the New York Times Magazine, a podcast series, and a school curriculum. The Project seeks to shape the popular understanding of American political development: America was not "born" on July 4th, 1776; rather, the country's true birthdate is August of 1619 when African slaves first arrived in colonial Virginia. The Project argues that "nearly everything that has truly made American exceptional," from its "economic might, its industrial power, its electoral system, diet and popular music, the inequities of its public health and education, its astonishing penchant for violence, its income inequality, the example its sets for the world as a land of freedom and equality, its slang, [and] its legal system" are all grounded, ultimately, in chattel slavery. The Project, thus, attempts to counter the centuries-long whitewashing of American history by flipping the nationalistic brand of American exceptionalism on its head.

I first learned of the 1619 Project through its critics. I read a series of now infamous interviews in the World Socialist Web Site (WSWS), all critiques of the Project, at the suggestion of a friend who wondered what I thought. Having taught at Wayne State University in Detroit, where the Socialist Equality Party - the group which runs the WSWS - is highly active in attempting to recruit students (the SEP is headquartered in nearby Oak Park, MI), I was aware of the website's editorial line regarding race. I found their position disagreeable, to put it mildly. Like some on the sectarian American Left, the SEP/WSWS has a tendency to underemphasize or ignore the existence of racial disparities, while perceiving any attempt to redress racial disparities as "identity politics." The latter, accordingly, is, at best, a bourgeois ploy to subvert working class activism away from the "more important" issue of class solidarity. ${ }^{2}$ They had also disrupted a talk on anti-fascism sponsored by the Abraham Lincoln Brigade Scholarship $^{3}$ I had recently attended, so, I was, to say the least, skeptical. I assumed the critiques would be standard "class reductionism": too much focus on race, not enough focus on class; too much identity, not enough working class solidarity.

However, credibility was restored when I saw the names of the people being interviewed: James Oakes, a distinguished historian of the US Civil War whose critiques of the so-called "New History of Capitalism" I've recommended to more colleagues than I can remember; Adolph Reed, Jr., one of the best-known living Marxist analysts of race in the US; Victoria E.

\footnotetext{
$\overline{2}$ See, e.g., "Perspectives and Tasks of the Socialist Equality Party" (2016).

${ }^{3}$ The Abraham Lincoln Brigade was a group of American volunteers who fought against the fascists during the Spanish Civil War. The scholarship — established by the proceeds from a benefit concert by Pete Seeger-is awarded in the memory of the Wayne State students who were members of the Brigade.
} 
Bynum, author of The Free State of Jones, a nuanced look at poor whites in the Deep South which was eventually adapted into a movie starring Matthew McConaughey; and others. They are respected scholars on questions of race, not sectarian party ideologues. Their positions, I thought, were at least worth engaging.

Those critics presented a plausible picture of what one might expect the New York Timesthe mouthpiece of American (neo)liberalism for generations - to produce: a neo-liberal interpretation of race, a neo-liberal interpretation of slavery, and a neo-liberal solution to racial inequality. Oakes excoriated the Project's reliance on the New History of Capitalism literature, which has a problematic tendency to simultaneously treat capitalism as the primary category of analysis, while never actually bothering to define what is meant by "capitalism" in the first place (see Kershaw 2020 for a perceptive review of this issue in the New History of Capitalism). As such, Oakes argues, the 1619 Project errs where the New Historians of Capitalism err: they conflate slavery and capitalism because they lack conceptually meaningful definitions of either economic system. According to the 1619 Project, then, slavery was just a "bad" version of capitalism; American capitalism, today, retains this badness because it is historically rooted in slavery. Had it not been for slavery, American capitalism would be just fine - just like other, more socially democratic capitalist states. Similarly, Reed argues in his response that the Project reduces every contemporary social ill to slavery, as if capitalism doesn't, by itself, exploit and oppress workers in an attempt to increase profitability. The conflation of slavery and capitalism produces a moral critique of American capitalism but disallows the meaningful sociological and political economic analysis necessary for a deeper, structural critique of capitalism (see, too, Clegg 2020, p. 76).

More seriously, Bynum, Oakes, James M. McPherson (Princeton historian), and Gordon S. Wood (Brown historian) accused the Project of serious factual errors and "distortions," while condemning the lack of transparency in the Project's fact-checking process in a letter principally authored by Sean Wilentz (Princeton historian; see, too, Wilentz's related article in The New York Review of Books). Here, the critics questioned the Project's characterization of the American Revolution as being fought to protect slavery, as well as the Project's negative portrayal of Abraham Lincoln.

In the context of that damning introduction, I read the 1619 issue of the New York Times Magazine. I was struck by two things: first, I assumed - given the critics disapproval of the fact-checking process and insufficient involvement of historians - that the issue would be predominantly authored by journalists, perhaps even anonymously. In fact, the issue is composed of individually authored articles written by historians and social scientists whose names I recognized as leaders in the field: Khalil Gibran Muhammad, Kevin M. Kruse, Matthew Desmond, and others. Second, I was stuck at how extraordinarily narrow the critiques of the Project were given the breadth of the issue.

I agree that the Project — particularly Desmond's contribution - tends to problematically conflate slavery and capitalism, as Oakes argues in detail. I agree, too, with Reed who says that the Project tends to let capitalism as a socio-economic system distinct from slavery off of the hook. The consequences of these mistakes have been discussed at length elsewhere, so I don't find it necessary to repeat them here (see Post 2017; 2012). However, the WSWS critiques have a troubling tendency to construct strawmen, extrapolating and imputing entire theories of race from rhetorical flourishes, while perceiving an omnipresence of neo-liberalism where I'm not sure it exists.

The 1619 Project has been accused of perpetuating a neo-liberal theory of race. But what is a neo-liberal theory of race? In my reading, a neo-liberal theory of race is one that treats racial 
inequality as being solely explicable in terms of the consequences of an ideology white people possess. In other words, white people possess an ideology—racism—which leads them to act in ways which result in racial inequality. Individual neo-liberal theories do vary as to what kind of white people are the primary actors: are all white people to blame, or just a subset of white people? Theories that make the latter claim are wont to blame poor whites - the white working class, white trash, deplorables - where racist ideology has no cause outside of dumb ignorance (see Maisano 2017). Theories that make the former claim portray racism as something which can be exorcised from the white mind with enough sensitivity training and self-criticism (see McWhorter 2020). Either way, white Liberals are (or can be) exonerated, and the problem lies simply with dumb, poor, ignorant whites, whose economic grievances can be safely ignored.

Neo-liberal theories of race are explicitly anti-materialist (Melamed 2006). Racial inequality is in no way grounded in economic relations, according to such theories. Indeed, in the quantitative analysis of American public opinion, the now popular "racial resentment" scale was developed, in part, as a neo-liberal alternative to economic explanations for racial policy preferences (Kinder and Sanders 1996). In short, for a theory of race to be considered neoliberal, the primary causal mechanism responsible for racial inequality is ideology, uncaused by and unconnected to economic relations.

The 1619 Project has also been accused of perpetuating a neo-liberal theory of slavery. It's less clear to me what is meant by this claim, but I assume it is something akin to what Barbara Fields (1990) suggests when she says that "probably a majority of American historians think of slavery in the United States as primarily a system of race relations - as though the chief business of slavery were the production of white supremacy rather than the production of cotton, sugar, rice and tobacco" (p. 99). So, a theory of slavery might be said to be neo-liberal if it claims that slavery existed primarily to produce racism rather than to produce commodities for profit.

Given these parameters, does the 1619 Project represent a neo-liberal theory of race and/or slavery? I'll focus here, as the WSWS critics do, on Desmond's response to that question. First, according to Desmond, was slavery in the US "primarily a system of race relations," or was it first and foremost an economic system used to aggrandize slaveowners? Desmond explicitly rejects the position that slavery, and the violence necessary to perpetuate it, was the result of "dumb racism." For Desmond, "it was not so much the rage of the poor white Southerner but the greed of the rich white planter that drove the lash." Thus, for all its shortcomings, the New History of Capitalism has heeded Fields' critique: for the NHC, slavery is first and foremost an economic system used to profitably produce commodities (hence its tendency to conflate slavery with capitalism). Desmond follows their lead in this regard.

Second, in terms of the question of why non-slaveholding whites buy into this system, Desmond again rejects the neo-liberal claim that ignorance and ideological racism are to blame. Here, Desmond makes two claims, both of which follow from a reading of W.E.B. Du Bois and his more materialist interpreters, like Theodore Allen and Alexander Saxton (see Roediger 2019, 47-72). First, white workers derive a "public and psychological wage" from white supremacy; their whiteness bestows on them social superiority. Second, and more importantly, whites derived the much more concrete benefit of not being slaves themselves. As Desmond put it, "witnessing the horrors of slavery drilled into poor white workers that things could be worse." So, why did poor whites, according to Desmond, buy in to white supremacy? Not because of ideological racism, but because - relative to enslaved Blacksthey derived concrete benefits from its operation.

In an even more materialist vein, Desmond argues that slavery creates a split-labor market, which pulls down the absolute wages of white workers while "dividing workers [slave and 
non-slave] from themselves." Here, Desmond makes the rather orthodox Marxist claim that racial inequality is primarily rooted in a racialized labor markets and top-down attempts to "divide and conquer" the working class. While poor whites do benefit relatively by the operation of white-supremacist social systems, they do not benefit absolutely. None of this strikes me as particularly neo-liberal.

What can we glean about the political demands of the Project? Are they, at least, neoliberal? Again, I don't think so. Desmond repeatedly stresses the importance of labor unions in reducing economic inequality, laments the growth of economic insecurity and the broader gig economy, while condemning widespread poverty wages. A short article by Jeneen Interlandi advocates strongly for universal healthcare, while Kevin M. Kruse's contribution promotes the expansion of public transit. Surely, this is not revolutionary socialism, but neither are they the neo-liberal ddemands of mainstream Democrats.

Gordon Wood ends his contribution to the WSWS critique by saying, "It's too bad that [The 1619 Project is] going out into the schools with the authority of the New York Times behind it. That's sad because it will color the views of all these youngsters who will receive the message of the 1619 Project." As a (former) youngster who received the message already being peddled by the American public education system with regard to race and slavery in the US, I find it hard to interpret Wood's claim with anything but sheer bewilderment. The official view of slavery and the US Civil War I was presented - at a majority Black school in the North — was one "colored" by white supremacist, Confederate sympathy. My experience in this regard, being taught the most reactionary version of US history with little context prior to college, is by no means an isolated one. Indeed, in one well known case, a high school geography textbook published by McGraw-Hill characterizes slaves as "immigrants" and "workers," a position that Reed actually defends in his WSWS response (Schaub 2015). There is little doubt in my mind that the overwhelming majority of American public school students would be better served than they currently are if they were simply locked in an empty room with the 1619 issue of the New York Times Magazine.

None of this is to say that the 1619 Project is perfect or beyond criticism. It does have a tendency toward moralism, its use of metaphor can be misleading, and its assertion that contemporary racial inequality is directly tied to slavery - rather than, say, the racialization of New Deal housing policies, the long run operation of racialized labor markets, etc. - can be, at times, quite strained. It also glosses over the important fact that capitalism is quite proficient at creating and perpetuating white supremacy all by itself. These are important points with equally important political implications: can capitalism be purged of its racial sins, or will capitalism inevitably transform and maintain racial difference?

Nevertheless, these points could have been made constructively instead of dismissively. The response to the Project by many prominent members of the American Left - a Left which has been accused, rightly or wrongly, of already having a "race problem"- has been, to put it generously, not a good look. Indeed, the similarity between the Left's response to the Project and the far-right's response has been remarkably similar, ${ }^{4}$ which should make those who sympathize with the WSWS critiques at least take pause.

\footnotetext{
${ }^{4}$ The right-wing National Association of Scholars submitted a letter in October 2020 to the Pulitzer Prize Board, eerily similar in its accusations to Wilentz's letter to the editor, asking the Board to rescind Nikole Hannah-Jones' Pulitzer Prize she received for her contribution to the 1619 Project. The letter was signed by a "who's who" of right-wing academics from the Hoover Institution, the Manhattan Institute, and the vehemently anti-socialist Hillsdale College, among others (see P. Wood 2020). In a truly strange article in the pro-capitalist Wall Street Journal, Elliot Kaufman (2019) positively cites the WSWS critiques, warning that "even communists now tell the Times to cool it."
} 
Some have accused the critics of the 1619 Project of having a "white historian" problem. While academia, as a whole, certainly has a diversity problem, I'm not sure that is the principal issue in this particular instance. Rather, the problem seems more like a "tenured professor far removed from the working class" problem. It seems to reflect the position of some Leftists who, because of their longstanding lack of political influence, become infatuated with being correct, rather than being politically relevant. The correct "line" replaces actual activism and broader connections to the working class. The 1619 Project should have been met with a critical, but constructive embrace by the Left - that is, if it wants to be relevant to contemporary struggles of the working class.

Acknowledgements The author would like to thank Charlie Post, Matthew Lacouture, Paul V. Kershaw, Anthony Marcus, Kristine Riley, Michelle L. Nakad, Alexander D. Starr, Mary E. White, Jason Lawrence, Michael Goldfield, and Stephen Steinberg for their comments and support.

Availability of data and material Not applicable

Code availability Not applicable

\section{Declarations}

Conflict of interest The author declares no competing interests.

\section{References}

Critics Letter to the Editor of the New York Times Magazine and the Editor's Response (accessed 12/19/2020): Silverstein, Jake. 2019. "We Respond to the Historians Who Critiqued the 1619 Project." The New York Times Magazine. https://www.nytimes.com/2019/12/20/magazine/we-respond-to-the-historians-whocritiqued-the-1619-project.html

London, Eric. 2019. "Historian Victoria Bynum on the Inaccuracies of the New York Times 1619 Project." World Socialist Web Site. https://www.wsws.org/en/articles/2019/10/30/bynu-o30.html

Mackaman, Tom. 2019a. “An Interview with Political Scientist Adolph Reed, Jr. on the New York Times' 1619 Project.” World Socialist Web Site. https://www.wsws.org/en/articles/2019/12/20/reed-d20.html

Mackaman, Tom. 2019b. "An Interview with Historian Gordon Wood on the New York Times' 1619 Project." World Socialist Web Site. https://www.wsws.org/en/articles/2019/11/28/wood-n28.html

Mackaman, Tom. 2019c. “An Interview with Historian James McPherson on the New York Times' 1619 Project.” World Socialist Web Site. https:/www.wsws.org/en/articles/2019/11/14/mcph-n14.html

Mackaman, Tom. 2019d. "An Interview with Historian James Oakes on the New York Times' 1619 Project." World Socialist Web Site. https://www.wsws.org/en/articles/2019/11/18/oake-n18.html

The 1619 Project: The New York Times Magazine, August 18, 2019.

Other Works Cited:

Clegg, John. 2020. A Theory of Capitalist Slavery. Journal of Historical Sociology 33 (1): 74-98.

Fields, Barbara. 1990. Slavery, Race and Ideology in the United States of America. New Left Review 181 (1): 95 118.

Kaufman, Elliot. 2019. “The '1619 Project' Gets Schooled.” Wall Street Journal. https:/www.wsj.com/articles/ the-1619-project-gets-schooled-11576540494

Kershaw, Paul V. 2020. Hamlet Without the Prince of Denmark: Bringing Capitalism Back into the 'New' History of Capitalism. Journal of Historical Sociology 33 (1): 61-73.

${ }_{5}^{5}$ This has been gleaned from a Twitter exchange between Hannah-Jones and Wesley Yang. Hannah-Jones later clarified her position (Serwer 2019). 
Kinder, Donald R., and Lynn M. Sanders. 1996. Divided by Color: Racial Politics and Democratic Ideals. Chicago: University of Chicago Press.

Maisano, Chris. 2017. The New 'Culture of Poverty. Catalyst 1 (2): 195-208.

McWhorter, John. 2020. The Dehumanizing Condescension of White Fragility. The Atlantic. https:/www. theatlantic.com/ideas/archive/2020/07/dehumanizing-condescension-white-fragility/614146/.

Melamed, Jodi. 2006. The Spirit of Neoliberalism: From Racial Liberalism to Neoliberal Multiculturalism. Social Text 24 (4): 1-24.

Post, Charles. 2012. The American Road to Capitalism: Studies in Class-Structure, Economic Development and Political Conflict, 1620-1877. Chicago: Haymarket.

Post, Charles. 2017. Slavery and the New History of Capitalism. Catalyst 1 (1): 172-192.

Roediger, David. 2019. Class, Race, and Marxism. London: Verso.

Schaub, Michael. 2015. Texas Textbook Calling Slaves 'Immigrants' to be Changed, After Mom's Complaint. Los Angeles Times. https:/www.latimes.com/books/jacketcopy/la-et-jc-texas-textbook-calls-slavesimmigrants-20151005-story.html.

Serwer, Adam. 2019. The Fight Over the 1619 Project is Not About the Facts. The Atlantic. https://www. theatlantic.com/ideas/archive/2019/12/historians-clash-1619-project/604093/.

Socialist Equality Party. 2016. "Perspectives and Tasks of the Socialist Equality Party." World Socialist Web Site. https://www.wsws.org/en/articles/2016/08/24/res1-a24.html

US News. 2020. "Belleville High School.” https:/www.usnews.com/education/best-high-schools/michigan/ districts/van-buren-public-schools/belleville-high-school-10347

Wood, Peter. 2020. "Pulitzer Board Must Revoke Nikole Hannah-Jones’ Prize." National Association of Scholars. https://www.nas.org/blogs/article/pulitzer-board-must-revoke-nikole-hannah-jones-prize

Publisher's note Springer Nature remains neutral with regard to jurisdictional claims in published maps and institutional affiliations. 